\title{
A Study On Consumer Brand Preference Towards Using Dth Service Providers In Coimbatore City
}

\author{
K.Myilswamy \\ Assistant Professor, Department Of Commerce With Computer Applications, Dr.Sns Rajalakshmi College Of \\ Arts And Science
}

\begin{abstract}
Marketing includes all activities which are concerned with effecting changes in the ownership and position of good and services". Direct marketing involves by passing the retailer in regarding in reaching the customer. . In this study there are five companies were included those are Sun Direct, Big TV, Digital TV, Dish TV, TATA Sky. Primary data were collected from 100 respondents by convenient sampling method through questionnaire and also by interview method in Coimbatore district. 15 respondents were selected to pilot study and based on their suggestions necessary modifications were made in the actual questionnaire. This study consists of simple percentage analysis to done keeping in mind the objectives of the study, chi - square parameters were employed to test the hypothesis spelt out in the study. Garrett ranking techniques was used to rank the preference of the respondents on different aspects of the study, the percentage position of each rank thus obtained into scores by referring to the table given by Henry E. Garrett. Analysis of variance to make two estimates of population variance those based on between sample variance and the other based on within variance are compare with $F$ - test table. The present study reveals that majority of the respondents preferred Big TV for more channels because they can pay for what they want to watch. The company can reduce the price to fulfill the needs for low-income level of people.
\end{abstract}

\section{Introduction:}

Marketing analysis includes finding out what group of potential customer exist, what group of customers you prefer to, what their needs are, what products or services you might develop to meet their needs, how the customers might prefer to use the products and services, what your competitor are doing, what pricing you should use and how you distribute products and services to your target markets.

\section{Need For The Study}

1) The growth of the economy contributes to the increased per capita income of the individuals.

2) In this project it is proposed to make on attempts to analyze the customer satisfaction.

3) The researcher would have like to recognize this separate set of customer and identify the factors, which gives them satisfaction.

4) Advertisement is the major role for improving the DTH services.

\section{Statement Of Problems}

The biggest changes have occurred in consumer a product by new \& innovative technology has used to satisfy the consumers. More models have been introduced by various manufactures in this content.This study is taken up in the various DTH which have considerable share in the market. This study will help to find out about the consumer preference towards DTH, its advantages, features etc. and also suggestions to improve the product.

\section{Objectives Of The Study}

1) To find out the factors considered by the DTH users at the time of purchase.

2) To evaluate the performance of the DTH service.

3) To know about the expectations of the customers.

4) To understand the attitude of the customers.

5) To providing possible suggestion to improve the service.

\section{Research Methodology}

"The procedures by which researchers go about their work of describing, explaining and predicting phenomena are called methodology".

SAMPLING TECHNIQUE: When the population elements are selected for inclusion in the sample based on the ease of access, it can be called convenience sampling. 
TYPE OF RESEARCH: This study is descriptive in nature. The descriptive research is one that describes something the demographic characteristics of the consumers who use the products.

DATA SOURCES: The major source, which was used for this study, was primary and the secondary data source.

PRIMARY DATA:The primary data collected with the help of structured questionnaires and interview method.Thequestionnaire was administrated to selected DTH users.

SECONDARY DATA:Secondary data was collected from various books, journals, and websites pertaining to this study.

TOOLS FOR ANALYSIS:In this study the collected data were analyzed by using percentage analysis, chi square test, ANOVA, Garrett ranking technique.

SAMPLE SIZE: The sample size is 100 respondents constituting all categories of people from Coimbatore district.

PILOT STUDY: Pilot study was conducted to test questionnaire. Based on the information given by 15 respondents, necessary modifications were made in the actual questionnaire.

AREA OF STUDY:This Study was conducted in Coimbatore city.

PERIOD OF STUDY: Period during November 2010 to April 2011

\section{Limitations Of The Study}

1) The result can be confined to Coimbatore city alone and not generalized for other areas.

2) Respondents opinion are dynamics, they keep changing time to time.

3) The time taken for this study was also limited and it was the major constraint to complete the work entirely.

\section{Analysis And Interpretation}

Personal Factors

\begin{tabular}{|c|c|c|c|c|c|}
\hline S.No & Source & Factors & $\begin{array}{c}\text { No. of } \\
\text { respondents }\end{array}$ & $\%$ & Total \\
\hline \multirow[b]{2}{*}{1} & \multirow{2}{*}{ GENDER } & Male & 66 & 66 & \multirow[b]{2}{*}{$100 \%$} \\
\hline & & Female & 34 & 34 & \\
\hline \multirow{4}{*}{2} & \multirow{4}{*}{$\begin{array}{c}\text { CLASSIFICATION ON } \\
\text { AGE GROUP }\end{array}$} & upto 20 years & 20 & 20 & \multirow{4}{*}{$100 \%$} \\
\hline & & 21 years- 35 years & 39 & 39 & \\
\hline & & 36 years- 50 years & 25 & 25 & \\
\hline & & above 51 years & 16 & 16 & \\
\hline \multirow{4}{*}{3} & \multirow{4}{*}{$\begin{array}{l}\text { OCCUPATION OF } \\
\text { RESPONDENTS }\end{array}$} & Business men & 22 & 22 & \multirow{4}{*}{$100 \%$} \\
\hline & & Professional & 28 & 28 & \\
\hline & & Agriculture & 10 & 10 & \\
\hline & & Employed & 40 & 40 & \\
\hline
\end{tabular}

PRODUCT DETAILS

\begin{tabular}{|c|c|c|c|c|c|}
\hline S.No & Source & Factors & $\begin{array}{c}\text { No . of } \\
\text { respondents }\end{array}$ & $\%$ & Total \\
\hline \multirow{5}{*}{4} & \multirow{5}{*}{$\begin{array}{l}\text { BRAND OF DTH } \\
\text { USING }\end{array}$} & Sun Direct & 32 & 32 & \multirow{5}{*}{$100 \%$} \\
\hline & & Big TV & 49 & 49 & \\
\hline & & Digital TV & 2 & 2 & \\
\hline & & Dish TV & 6 & 6 & \\
\hline & & TATA Sky & 5 & 5 & \\
\hline \multirow{2}{*}{5} & \multirow{2}{*}{$\begin{array}{l}\text { SATISFIED WITH } \\
\text { THE CHANNELS }\end{array}$} & Yes & 68 & 68 & \multirow{2}{*}{$100 \%$} \\
\hline & & No & 32 & 32 & \\
\hline \multirow{4}{*}{6} & \multirow{4}{*}{$\begin{array}{l}\text { TYPE OF } \\
\text { CHANNELS }\end{array}$} & English channel & 32 & 32 & \multirow{4}{*}{$100 \%$} \\
\hline & & Tamil channels & 45 & 45 & \\
\hline & & Sports channels & 12 & 12 & \\
\hline & & Others & 11 & 11 & \\
\hline \multirow{4}{*}{7} & \multirow{4}{*}{ PURPOSE OF USING } & Easy recharge & 40 & 40 & \multirow{4}{*}{$100 \%$} \\
\hline & & Less charge & 39 & 39 & \\
\hline & & Providing many channels & 12 & 12 & \\
\hline & & Others & 09 & 09 & \\
\hline
\end{tabular}




\begin{tabular}{|c|c|c|c|c|c|}
\hline \multirow{4}{*}{8} & \multirow{4}{*}{$\begin{array}{c}\text { OPINION ABOUT } \\
\text { COST }\end{array}$} & Reasonable & 30 & 30 & \multirow{4}{*}{$100 \%$} \\
\hline & & Economical & 39 & 39 & \\
\hline & & Moderate & 12 & 12 & \\
\hline & & No idea & 19 & 19 & \\
\hline \multirow{3}{*}{9} & \multirow{3}{*}{$\begin{array}{l}\text { COMPARISON OF } \\
\text { WORKING }\end{array}$} & Satisfied & 40 & 40 & \multirow{3}{*}{$100 \%$} \\
\hline & & Moderate & 48 & 48 & \\
\hline & & Dissatisfied & 12 & 12 & \\
\hline \multirow{3}{*}{10} & \multirow{3}{*}{$\begin{array}{l}\text { OPINION ABOUT } \\
\text { THE CUSTOMER } \\
\text { CARE }\end{array}$} & Very good & 58 & 58 & \multirow{3}{*}{$100 \%$} \\
\hline & & Good & 37 & 37 & \\
\hline & & bad & 05 & 05 & \\
\hline \multirow{2}{*}{11} & \multirow{2}{*}{$\begin{array}{l}\text { PROBLEM WHILE } \\
\text { NORMAL SEASON }\end{array}$} & Yes & 69 & 69 & \multirow{2}{*}{$100 \%$} \\
\hline & & No & 31 & 31 & \\
\hline \multirow{2}{*}{12} & \multirow{2}{*}{$\begin{array}{l}\text { PROBLEM WHILE } \\
\text { RAINY SEASON }\end{array}$} & Yes & 100 & 100 & \multirow{2}{*}{$100 \%$} \\
\hline & & No & 0 & 0 & \\
\hline \multirow{4}{*}{13} & \multirow{4}{*}{$\begin{array}{l}\text { OPINION ABOUT } \\
\text { AFTER SALES } \\
\text { SERVICE }\end{array}$} & Excellent & 47 & 47 & \multirow{4}{*}{$100 \%$} \\
\hline & & Good & 42 & 42 & \\
\hline & & Average & 9 & 9 & \\
\hline & & $\mathrm{Bad}$ & 2 & 2 & \\
\hline
\end{tabular}

1) Majority $66 \%$ of the respondents are male.

2) Majority $39 \%$ of the respondents age between 21 years-35 years.

3) Majority $40 \%$ of the respondents comes under employed category

4) Majority $49 \%$ of them are using Big TV

5) Majority $68 \%$ of the respondents satisfied with channels

6) Majority $45 \%$ of them prefer Tamil channels.

7) Majority $40 \%$ of them prefer easy recharge

8) Majority $39 \%$ of them told cost of brand is economical.

9) Majority $48 \%$ of them told comparison of working is moderate.

10) Hence it can be concluded that majority $58 \%$ of the respondents are opined very good about customer care.

11) Majority $69 \%$ of the respondents are told they are facing problem while normal season.

12) $100 \%$ of the respondents are facing problem in rainy season.

13) Majority $47 \%$ of the respondent's opinion about after sales service is Excellent.

\section{TESTING OF HYPOTHESIS}

Chi - Square Test $\left(\chi^{2}\right)$

1) $\mathrm{H}_{0}$ : There is no significant relationship between the gender \&satisfaction with channel provided by DTH services

2) $\mathrm{H}_{0}$ : There is no significant relationship between the gender and type of channels provided by DTH services

\begin{tabular}{|c|c|c|c|c|}
\hline & $\begin{array}{c}\text { CALCULATED } \\
\text { VALUE }\end{array}$ & $\begin{array}{c}\text { TABLE } \\
\text { VALUE }\end{array}$ & $\begin{array}{c}\text { DEGREE OF } \\
\text { FREEDOM }\end{array}$ & $\begin{array}{c}\text { RESULT OF 5\% } \\
\text { LEVEL }\end{array}$ \\
\hline 1 & 0.920 & 3.841 & 1 & Significant \\
\hline 2 & 0.458 & 7.815 & 3 & Significant \\
\hline
\end{tabular}

Source : Primary Data

1) Hence the test proved significant relationship between gender and satisfaction with channels and hence the null hypothesis should be rejected at $5 \%$ level.

2) Hence the test proved significant relationship between gender and type of channels and hence the null hypothesis should be rejected at $5 \%$ level.

\section{Anova Table}

Relationship Between Opinion Regarding Working And Gender

$\mathbf{H}_{\mathbf{0}}$ :There is no significant relationship between opinion regarding working and gender

\begin{tabular}{|c|c|c|c|c|c|}
\hline $\begin{array}{c}\text { SOURCE OF } \\
\text { VARIANCE }\end{array}$ & $\begin{array}{c}\text { SUM OF } \\
\text { SQUARE }\end{array}$ & $\begin{array}{c}\text { DEGREE OF } \\
\text { FREEDOM }\end{array}$ & $\begin{array}{c}\text { MEAN } \\
\text { SQUARE }\end{array}$ & $\begin{array}{c}\text { VARIANCE RATIO } \\
\text { (F-RATIO) }\end{array}$ & $\begin{array}{c}\text { 5\% FACTOR } \\
\text { LIMIT }\end{array}$ \\
\hline Between columns & 170.667 & 1 & 170.67 & 13.474 & 18.51 \\
\hline Between rows & 357.333 & 2 & 178.67 & 14.105 & 9.55 \\
\hline Residual & 25.333 & 2 & 12.67 & & \\
\hline
\end{tabular}

Source : Primary Data 
Between Columns:The calculated value of 13.474is less than the table value of 18.51at 5\% level of significance. So the null hypothesis is accepted.

Between Rows:The calculated value of 14.105 is more than the table value of $9.55 \mathrm{at} 5 \%$ level of significance. So the null hypothesis is rejected.

\section{Relationship Between Opinion Aboutcost And Occupation}

$\mathrm{H}_{0}$ : There is no significant relationship between opinion about cost and occupation

\begin{tabular}{|c|c|c|c|c|c|}
\hline $\begin{array}{c}\text { SOURCE OF } \\
\text { VARIANCE }\end{array}$ & $\begin{array}{c}\text { SUM OF } \\
\text { SQUARE }\end{array}$ & $\begin{array}{c}\text { DEGREE } \\
\text { OF } \\
\text { FREEDOM }\end{array}$ & $\begin{array}{c}\text { MEAN } \\
\text { SQUARE }\end{array}$ & $\begin{array}{c}\text { VARIANCE } \\
\text { RATIO } \\
\text { (F-RATIO) }\end{array}$ & $\begin{array}{c}\text { 5\% } \\
\text { FACTOR } \\
\text { LIMIT }\end{array}$ \\
\hline Between columns & 106.5 & 3 & 35.5 & 2.719 & 3.86 \\
\hline Between rows & 117 & 3 & 39 & 2.987 & 3.86 \\
\hline Residual & 117.5 & 9 & 13.06 & & \\
\hline
\end{tabular}

Source : Primary Data

Between Columns:The calculated value of 2.719is more than the table value of 3.86at 5\% level of significance. So the null hypothesis is rejected.

Between Rows:The calculated value of 2.987is more than the table value of 3.86at 5\% level of significance. So the null hypothesis is rejected.

\section{Garrett Ranking Technique}

Factors To Select Brand

\begin{tabular}{|c|l|c|c|c|}
\hline S.NO & \multicolumn{1}{|c|}{ FACTORS } & TOTAL SCORES & MEAN SCORES & RANK \\
\hline 1 & Price & 5050 & 50.50 & III \\
\hline 2 & Good clarity & 4600 & 46.00 & $\mathrm{~V}$ \\
\hline 3 & Offers & 5722 & 57.22 & $\mathrm{I}$ \\
\hline 4 & Sound clarity & 5717 & 57.17 & $\mathrm{II}$ \\
\hline 5 & Channels & 4689 & 46.89 & $\mathrm{IV}$ \\
\hline
\end{tabular}

Source: Primary Data

The table shows that the factors to select the brand of DTH service"Offers "was ranked firsts with total score of $\mathbf{5 7 2 2}$ and mean score of 57.22. "Sound clarity" occupied second position with the total score of 5717 and mean score of 57.17. "Price" occupied third position with the total score of 5050 and mean score of 50.50. "channels" occupied fourth position with the total score of 4689 and mean score of 46.89. "Good clarity" occupied fifth position with the total score of 4600 and mean score of 46.00 .It can be concluded that the factor offer was ranked as first.

\section{Suggestions}

1) DTH provider has to increase various awareness programs to create brand image

2) Improve the package of the DTH and add more channels.

3) DTH service providers should reduce the cost of the product by which they can ask to retain their customer.

4) Advertisement of the DTH should be more effective and attractive

\section{Conclusion}

It is concluded from this study that the DTH service providers should improve the advertisement. The attractive advertisement give more sales. The company can reduce the price to fulfill the needs for low-income level of people. Add more packages and same more Tamil channels make your child genius. The present study reveals that majority of the respondents preferred Big TV for more channels because they can pay for what they want to watch.

\section{Books:}

\section{Bibliography}

[1] P.Saravanavel, "Research Methodology", Published by KitabMahal, 2006

[2] R.S.N.Pillai, Bagavathi, "Modern Marketing", S.Chand and company Ltd, 2007.

[3] C.R.Kothari, "Research Methodology", New age international Publishers, 2006.

Website:

[1] www.sundirect.com

[2] www.bigtv.com

[3] www.airteldigitaltv.com

[4] www.tatasky.com

[5] www.google.com 